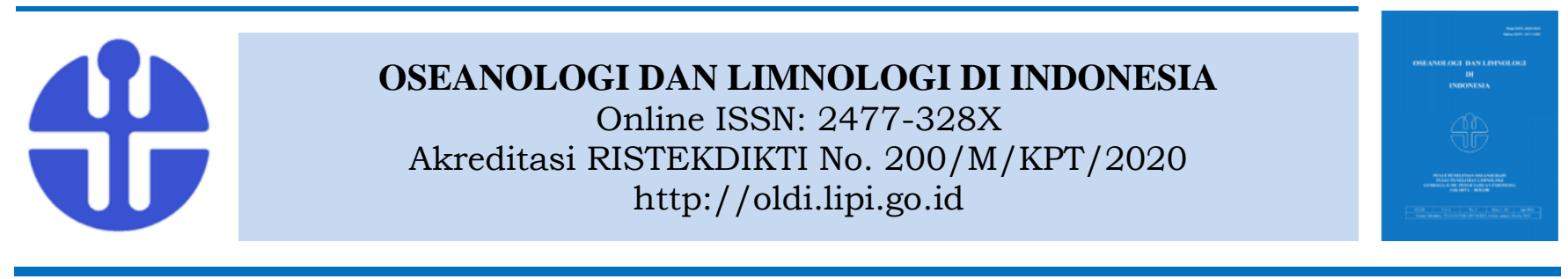

\title{
Pemodelan Sistem Karbonat di Laut Jawa
}

\author{
Alan Frendy Koropitan 1 \\ ${ }^{1}$ Departemen Ilmu dan Teknologi Kelautan, Fakultas Perikanan dan Ilmu Kelautan, Institut Pertanian Bogor, \\ Kampus IPB Darmaga Bogor, 16680 \\ Email: alan@apps.ipb.ac.id
}

Submitted 12 September 2021. Reviewed 18 September 2021. Accepted 26 October 2021.

DOI: 10.14203/oldi.2021.v6i3.375

\begin{abstract}
Abstrak
Kebakaran hutan di Kalimantan berpotensi meningkatkan konsentrasi $\mathrm{CO}_{2}$ di atmosfer, selain aktifitas pembakaran minyak bumi secara global, yang berdampak pada pertukaran gas $\mathrm{CO}_{2}$ udara-laut di Laut Jawa sehingga dapat merubah kesetimbangan sistem karbonat laut. Studi ini menggunakan model karbonat laut untuk mengkaji proses-proses yang mengontrol fluks $\mathrm{CO}_{2}$ di Laut Jawa dan kaitannya dengan kenaikan $\mathrm{CO}_{2}$ di atmosfer. Model karbonat laut ini menggunakan OCMIP-2 (Ocean Carbon-Cycle Model Intercomparison Model Project, Phase-2) yang digabung kedalam model ekosistem laut. Hasil model memperlihatkan adanya perbedaan besaran fluks karbon udara-laut pada Februari dan Oktober 2000. Februari 2000 dengan kecepatan angin yang lebih besar umumnya menghasilkan fluks yang lebih besar dibanding Oktober 2000. Namun demikian, pengaruh kecepatan angin berkurang ketika terjadi kenaikan $\mathrm{CO}_{2}$ yang signifikan di atmosfer. Secara umum, Laut Jawa berfungsi sebagai pelepas karbon di atmosfer akibat pengaruh dari temperatur permukaan yang relatif tinggi untuk perairan tropis Laut Jawa. Dalam hal ini, peranan solubility pump lebih besar dibanding penyerapan karbon oleh proses biologi. Selanjutnya, kenaikan $\mathrm{CO}_{2}$ di atmosfer dapat merubah kesetimbangan tekanan parsial. Untuk kasus kebakaran hutan $2002\left(\mathrm{CO}_{2}\right.$ atmosfer $\left.=460 \mathrm{ppm}\right)$, nilai pelepas karbon Laut Jawa lebih kecil dibanding sebelum kebakaran hutan dan bahkan menjadi penyerap karbon ketika $\mathrm{CO}_{2}$ di atmosfer ketika naik menjadi 1135,2 ppm berdasarkan skenario SSP tertinggi pada tahun 2100. Pemodelan ini juga memperlihatkan adanya persoalan asidifikasi laut serta sanggup menduga secara cepat perubahan ekosistem laut di masa depan akibat dampak kenaikan $\mathrm{CO}_{2}$ di atmosfer.
\end{abstract}

Kata kunci: Model karbonat laut, Laut Jawa, fluks karbon udara-laut.

\begin{abstract}
Modeling Carbonate System in the Java Sea. Besides the global fossil fuel burning activities, forest fires in Kalimantan could potentially increase atmospheric $\mathrm{CO}_{2}$ concentrations, impacting air-sea $\mathrm{CO}_{2}$ gas exchange in the Java Sea and changing the balance of the marine carbonate system. This study uses a marine carbonate model to examine the processes that control $\mathrm{CO}_{2}$ flux in the Java Sea and their relationship to $\mathrm{CO}_{2}$ increase in the atmosphere. OCMIP-2 (Ocean Carbon-Cycle Model Intercomparison Model Project, Phase-2) is performed in this marine carbonate model coupled with the marine ecosystem model. The model results show that the quantity of carbon air flux differs during February and October 2000. More considerable flux is produced during February 2000, where the wind speeds are higher than in October 2000. However, the wind speeds have less impact when the $\mathrm{CO}_{2}$ level in the atmosphere rises significantly. Due to the influence of a relatively high surface temperature in the tropical Java sea, the Java Sea functions as a carbon source to the atmosphere in general. In this case, the role of the solubility pump is more significant
\end{abstract}


than that of biological processes in carbon absorption. Moreover, increased $\mathrm{CO}_{2}$ in the atmosphere could alter the partial pressure equilibrium. In the case of 2002 forest fires (atmospheric $\mathrm{CO}_{2}=460 \mathrm{ppm}$ ), the carbon source of the Java Sea was less than before forest fires and even became carbon sink when atmospheric $\mathrm{CO}_{2}$ rose to $1135.2 \mathrm{ppm}$ based on the highest SSP scenario in 2100. This modeling also reveals marine acidification issues and could rapidly assess the future changes in marine ecosystems due to $\mathrm{CO}_{2}$ levels rising in the atmosphere.

Keywords: Marine carbonate model, Java Sea, air-sea carbon flux.

\section{Pendahuluan}

Pengontrolan emisi gas rumah kaca semakin intens akhir-akhir ini dengan berbagai skenario yang ada. Rekomendasi terbaru dari IPCC (2021) menegaskan bahwa upaya membatasi pemanasan global yang disebabkan oleh manusia ke tingkat tertentu memerlukan pembatasan emisi $\mathrm{CO}_{2}$ kumulatif, setidaknya emisi $\mathrm{CO}_{2}$ neto mencapai angka nol. Sejalan dengan itu, juga pengurangan yang kukuh dalam emisi gas rumah kaca lainnya. Pada tahun 2019, IPCC (2021) melaporkan bahwa konsentrasi $\mathrm{CO}_{2}$ di atmosfer lebih tinggi dibanding era lainnya setidaknya dalam 2 juta tahun dan konsentrasi $\mathrm{CH}_{4}$ dan $\mathrm{N}_{2} \mathrm{O}$ lebih tinggi setidaknya dalam 800.000 tahun ini. Dalam hal ini, Global Carbon Project (GCP) 2020 (Friedlingstein et al., 2020) menyebutkan kenaikan konsentrasi $\mathrm{CO}_{2}$ di atmosfer dari tahun 1750 sekitar 277 ppm menjadi 410 ppm pada tahun 2019, atau naik 48\%. Pada era pandemi COVID-19 ini, GCP 2020 memproyeksikan adanya penurunan emisi $\mathrm{CO}_{2}$ global dari minyak bumi sebesar $7 \%$ dibanding 2019. Kondisi ini pada sisi lain dapat memotivasi upaya pengurangan emisi $\mathrm{CO}_{2}$ ke atmosfer, walaupun tren kenaikan sudah mulai terlihat, namun belum mencapai angka emisi seperti 2019.

Dalam laporan sintesis GCP 2020, estimasi emisi global $\mathrm{CO}_{2}$ antropogenik pada periode 2010-2019 mencapai 40,1 $\mathrm{GtCO}_{2} /$ tahun (setara $10,94 \mathrm{GtC} /$ tahun), dimana sumber terbesar dari penggunaan minyak bumi $(86 \%)$ dan sisanya berasal dari perubahan lahan (14\%). Emisi ini selanjutnya tertinggal di atmosfer sebesar $46 \%$, kemudian $31 \%$ diserap oleh vegetasi daratan dan $23 \%$ diserap oleh samudera. Secara khusus penyerapan $\mathrm{CO}_{2}$ oleh laut, GCP 2020 melaporkan adanya peningkatan dari $1,0 \pm 0,3 \mathrm{GtC} /$ tahun pada 1960-an menjadi 2,5 $\pm 0,6 \mathrm{GtC} /$ tahun 2010-2019. Perkembangan terbaru, Gruber et al. (2019) mengamati adanya penyimpangan regional yang jelas dari pola serapan $\mathrm{CO}_{2}$ antropogenik samudera untuk periode 1994-2007, yaitu tidak ada jaminan bahwa penyerapan samudera akan tetap kuat seiring waktu.
Terkait fluks pertukaran $\mathrm{CO}_{2}$ di lapisan udara-laut ini, tantangan mendasar adalah memahami secara mekanistik proses pertukaran $\mathrm{CO}_{2}$ kontemporer yang terdiri dari fluks $\mathrm{CO}_{2}$ yang sudah ada pada masa praindustri (alami) dan diasumsikan berubah sedikit sejak itu, dan fluks $\mathrm{CO}_{2}$ antropogenik akibat gangguan antropogenik dalam $\mathrm{CO}_{2}$ atmosfer (antropogenik). Untuk samudera, hasil integrasi global fluks $\mathrm{CO}_{2}$ antropogenik menyerap 2,2 $\pm 0,3 \mathrm{PgC} /$ tahun $(\mathrm{PgC}$ setara dengan GtC) (Mikaloff Fletcher et al., 2006) (untuk tahun nominal 1995) sedangkan fluks $\mathrm{CO}_{2}$ alami berfungsi sebagai pelepas sebesar $0,5 \pm 0,2 \mathrm{PgC} /$ tahun, dimana ini hampir seluruhnya dipengaruhi oleh sungai sebagai pelepas $\mathrm{CO}_{2}$ (Gruber et al., 2009).

Fluks $\mathrm{CO}_{2}$ alami dan antropogenik ini diperkirakan akan banyak berubah di masa depan sebagai respons terhadap peningkatan $\mathrm{CO}_{2}$ atmosfer yang terus-menerus dan perubahan iklim global. Sebagai contoh di lapisan udara-laut perairan tropis samudera, fluks neto $\mathrm{CO}_{2}$ kontemporer umumnya berfungsi sebagai pelepas, sementara fluks neto $\mathrm{CO}_{2}$ antropogenik berfungsi sebagai penyerap, sedangkan fluks neto $\mathrm{CO}_{2}$ alami berfungsi sebagai pelepas $\mathrm{CO}_{2}$ ke atmosfer. Berbeda dengan perairan dingin (lintang tinggi), semua fluks neto $\mathrm{CO}_{2}$, baik kontemporer, antropogenik dan alaminya berfungsi sebagai penyerap $\mathrm{CO}_{2}$ ke atmosfer. Tentunya besaran masing-masing fluks $\mathrm{CO}_{2}$ berbeda untuk arah yang sama (sama-sama penyerap atau pelepas) (Gruber et al., 2009). Tren ke depan, memperlihatkan bahwa daerah tropis sedang dalam proses berubah dari sumber $\mathrm{CO}_{2}$ menjadi penyerap $\mathrm{CO}_{2}$ (Hauck et al., 2020).

Perairan pesisir dicirikan sebagai penyerap $\mathrm{CO}_{2}$ untuk perairan lintang sedang dan tinggi, namun berperan sebagai pelepas $\mathrm{CO}_{2}$ di perairan lintang rendah dan di tropis, dengan kerapatan fluks $\mathrm{CO}_{2}$ rata-rata tahunan sebanding dalam besaran dan polanya dengan samudera yang berdekatan dengan pengecualian sistem yang didominasi sungai (Roobaert et al., 2019). Hasil integrasi global memperlihatkan perairan pesisir bertindak sebagai penyerap $\mathrm{CO}_{2}$ dengan laju 0,26 
$\mathrm{PgC} /$ tahun dan $0,2 \pm 0,02 \mathrm{PgC} /$ tahun untuk hasil kajian masing-masing Laruelle et al. (2018) dan Roobaert et al. (2019).

Secara khusus penelitian terbaru di perairan Indonesia memperlihatkan bahwa untuk Laut Jawa dan sekitarnya memang berfungsi sebagai pelepas $\mathrm{CO}_{2}$ ke atmosfer berdasarkan data pengukuran tekanan parsial $\mathrm{CO}_{2}$ permukaan laut $p \mathrm{CO}_{\text {2laut }}$ (Kartadikaria et al., 2015). Namun, laporan yang sama memperlihatkan ada wilayah perairan di utara Bali yang berfungsi sebagai penyerap $\mathrm{CO}_{2}$. Laporan ini menyimpulkan bahwa Laut Jawa menjadi sumber utama pelepas $\mathrm{CO}_{2}$ di perairan Indonesia akibat masukan bahan organik yang tinggi dari daratan, khususnya wilayahwilayah dengan pemukiman perkotaan yang padat, sementara peranan temperatur kurang berpengaruh.

Pada penelitian lain di Laut Jawa (Koropitan \& Ikeda, 2016), dengan menggunakan model 3-dimensi karbonat laut, hidrodinamika, dan ekosistem laut memperlihatkan hasil yang sama yaitu Laut Jawa sebagai pelepas $\mathrm{CO}_{2}$. Namun penyebab utama adalah pengaruh temperatur laut yang tinggi di perairan Indonesia yang tropis. Masukan daratan berupa nutrien tinggi melalui sungai-sungai dari pulau-pulau utama di sekitar Laut Jawa sudah dihitung dalam model berupa hasil pengukuran yang dikompilasi pada 21 sungai yang tersebar di Pulau Sumatera bagian tenggara, Pulau Kalimantan bagian selatan dan Pulau Jawa bagian utara. Hasil model ini menyebutkan bahwa memang masukan nutrien dari daratan dapat menyebabkan tingginya produktivitas primer di perairan pesisir Laut Jawa yang mampu menyerap $\mathrm{CO}_{2}$ di atmosfer, namun pengaruhnya tidaklah besar dalam pertukaran fluks $\mathrm{CO}_{2}$ di permukaan laut yang lebih dikontrol oleh pengaruh temperatur terhadap daya larut gas di laut (solubility pump). Hasil model sebaran nutrien dari sungai-sungai ini tidak menyebar merata ke seluruh Laut Jawa, tapi hanya terkosentrasi di perairan pesisir dari ketiga pulau tersebut.

Hasil pengukuran masukan karbon baik bentuk organik dan anorganik terlarut maupun partikel dari sungai-sungai di Indonesia menunjukkan hasil paling tinggi dari negaranegara lainnya di perairan Laut Tiongkok Selatan dan sekitarnya (Huang et al., 2017). Tetapi kajian Hamzah et al. (2020) yang khusus di sekitar Laut Jawa bagian barat melaporkan bahwa perairan ini tetap sebagai pelepas $\mathrm{CO}_{2}$, namun belum bisa menyimpulkan dengan tegas pengaruh masukan dari sungai dalam pertukaran gas $\mathrm{CO}_{2}$ udara-laut.
Penelitian Wirasatriya et al. (2020) dengan menggunakan data satelit malah menyimpulkan berbeda, dimana berpengaruh kecepatan angin dan salinitas permukaan lebih dalam pertukaran gas ini, walaupun sama melaporkan bahwa Laut Jawa sebagai pelepas $\mathrm{CO}_{2}$.

Dinamika pertukaran gas $\mathrm{CO}_{2}$ udara-laut erat kaitannya dengan sistem karbonat laut, dimana sistem ini juga berfungsi sebagai penyangga $\mathrm{pH}$ di laut. Peranan $p \mathrm{CO}_{2}$ laut menjadi salah satu faktor utama dalam pertukaran gas ini atau fluks karbon udara-laut. Dengan tren kenaikan $\mathrm{CO}_{2}$ di atmosfer selama ini, bagaimana dampaknya pada sistem karbonat laut? Bagaimana $\mathrm{pH}$ di perairan laut bisa berubah padahal ada pemahaman tentang sistem penyangga? Kajiankajian terbaru yang dibahas sebelumnya belum membahas dampak kenaikan $\mathrm{CO}_{2}$ di atmosfer akibat kebakaran hutan di daratan. Laporan kebakaran hutan Indonesia semakin meningkat dengan adanya periode kekeringan (El Niño yang kuat), misalnya pada tahun 1997 emisi karbon mencapai $989 \mathrm{TgC}$ dan pada 2015 mencapai 365 $\mathrm{TgC}$ (berdasarkan Global Fire Emissions Database version 4/GFED4s, sebagaimana dijelaskan dalam van der Werf et al., 2017), dimana Huijnen et al. (2016) melaporkan bahwa tingkat emisi rata-rata $11,3 \mathrm{TgCO}_{2} /$ hari selama September-Oktober 2015. Untuk itu, penelitian ini bertujuan mengkaji proses-proses yang mengontrol fluks $\mathrm{CO}_{2}$ di Laut Jawa dan kaitannya dengan kenaikan $\mathrm{CO}_{2}$ di atmosfer khususnya pasca kebakaran hutan di Kalimantan Tengah dan skenario perubahan iklim pada tahun 2100 .

\section{Metodologi}

Persamaan-persamaan yang digunakan dalam model ini adalah gabungan model ekosistem dan karbonat laut dimana penyelesaiannya berdasarkan metode numerik. Pendekatan ruang yang digunakan adalah 1dimensi vertikal di perairan selatan Provinsi Kalimantan Tengah, pada posisi $4.5^{\circ}$ LS dan $113.5^{\circ} \mathrm{BT}$, dimana jarak dari garis pantai sekitar 70 mil. Input pembangkit secara fisis adalah proses percampuran secara vertikal (vertical eddy diffusivity) yang dipengaruhi oleh pasut dan angin. Proses percampuran ini diperoleh dari hasil model 3-dimensi hidrodinamika Laut Jawa yang digunakan pada penelitian sebelumnya (Koropitan \& Ikeda, 2008).

Model ekosistem terdiri kompartemen nitrogen inorganik terlarut (DIN), fitoplankton $(\mathrm{F})$, zooplankton (Z) dan detritus (D), berdasarkan 
model yang dikembangkan Denman \& Peña (1999). Persaman-persamaan yang digunakan dalam model eksosistem adalah:

$\frac{\partial D I N}{\partial t}+\frac{\partial D I N \omega}{\partial \sigma}=\frac{\partial}{\partial \sigma}\left[\frac{K_{H}}{H} \frac{\partial D I N}{\partial \sigma}\right]+A_{5} D+A_{4} Z-A_{1} F$

$\frac{\partial F}{\partial t}+\frac{\partial F \omega}{\partial \sigma}=\frac{\partial}{\partial \sigma}\left[\frac{K_{H}}{H} \frac{\partial F}{\partial \sigma}\right]+A_{1} F-A_{3} Z-A_{2} F$

$\frac{\partial Z}{\partial t}+\frac{\partial Z \omega}{\partial \sigma}=\frac{\partial}{\partial \sigma}\left[\frac{K_{H}}{H} \frac{\partial Z}{\partial \sigma}\right]+(1-\gamma) A_{3} Z-A_{4} Z$

$\frac{\partial D}{\partial t}+\frac{\partial D \omega}{\partial \sigma}=\frac{\partial}{\partial \sigma}\left[\frac{K_{H}}{H} \frac{\partial D}{\partial \sigma}\right]+\gamma A_{3} Z+A_{4} Z-A_{5} D$

dimana: $\mathrm{t}=$ waktu; $\sigma=$ lapisan sigma secara vertikal berdasarkan Princeton Ocean Model, $\omega=$ komponen kecepatan vertikal (untuk sigma koordinat), $\mathrm{H}=$ kedalaman dan $\mathrm{K}_{\mathrm{H}}=$ koefisien eddy vertikal.

N-uptake, pemanfaatan nitrogen untuk pertumbuhan fitoplankton:

$$
\begin{aligned}
& A_{1} F=V_{m} \frac{I}{I_{o p t}} \exp \left(1-\frac{I}{I_{o p t}}\right)\left(\frac{D I N}{K_{N}+D I N}\right) F \\
& I=I_{0} \exp \left(-\int_{0}^{\sigma} \kappa d \sigma\right)
\end{aligned}
$$

dimana: $\mathrm{V}_{\mathrm{m}}=$ laju uptake maksimum fitoplankton, $\mathrm{I}=$ intensitas cahaya, $\mathrm{I}_{\mathrm{opt}}=$ pemanfaatan cahaya optimum untuk pertumbuhan fitoplankton, $\mathrm{K}_{\mathrm{N}}=$ konstanta half-saturation DIN, $\mathrm{I}_{\mathrm{o}}=$ intensitas cahaya di permukaan dan $\mathrm{\kappa}=$ koefisien ekstingsi cahaya. $\mathrm{K}$ adalah fungsi dari atenuasi cahaya oleh air laut $\left(\alpha_{1}\right)$ dan self-shading fitoplankton $\left(\alpha_{2}\right)$, sebagai berikut:

$\mathrm{K}=\alpha_{1}+\alpha_{2} \mathrm{~F}$

Pemangsaan oleh zooplankton:

$A_{3} Z=R_{m}(1-\exp (-A F)) Z$

dimana: $\mathrm{R}_{\mathrm{m}}=$ laju pemangsaan maksimum dan $\Lambda=$ konstanta Ivlev.

Nilai-nilai koefisien yang digunakan dalam model ekosistem ini beserta defenisinya dapat dilihat pada Tabel 1. Penjelasan nilai-nilai koefisien ini telah diuraikan oleh Koropitan \& Ikeda (2016).

Model karbonat laut pada umumnya mengacu pada Orr et al. (2001) dan Orr (2002), khususnya fase ke-2 (OCMIP-2). Berikut ini adalah deskirpsi umum mengenai sistem karbonat di laut dan pendekatan yang digunakan dalam perhitungan model dengan mengacu pada Dickson (2007). Dalam suatu sistem perairan laut, ketika $\mathrm{CO}_{2}$ terlarut dalam air akan membentuk asam karbonat $\left(\mathrm{H}_{2} \mathrm{CO}_{3}\right)$ dan selanjutnya terdisosiasi menjadi ion bikarbonat $\left(\mathrm{HCO}_{3}{ }^{2-}\right)$ dan karbonat $\left(\mathrm{CO}_{3}{ }^{2-}\right)$, dimana persamaan reaksi yang terbentuk adalah sebagai berikut:

$\mathrm{CO}_{2(\mathrm{~g})}=\mathrm{CO}_{2(\mathrm{aq})}$

$\mathrm{CO}_{2(\mathrm{aq})}+\mathrm{H}_{2} \mathrm{O}(\mathrm{l})=\mathrm{H}_{2} \mathrm{CO}_{3(\mathrm{aq}}$

$\mathrm{H}_{2} \mathrm{CO}_{3(\mathrm{aq})}=\mathrm{HCO}_{3^{-}}{ }_{(\mathrm{aq})}+\mathrm{H}^{+}{ }_{(\mathrm{aq})}$

$\left.\mathrm{HCO}_{3^{-}}{ }_{(\mathrm{aq}}\right)+\mathrm{H}_{2} \mathrm{O}{ }_{(\mathrm{aq})}=\mathrm{CO}_{3}{ }^{2-}{ }_{(\mathrm{aq})}+\mathrm{H}^{+}{ }_{(\mathrm{aq})}$

Tabel 1. Nilai konstanta yang digunakan dalam model

\begin{tabular}{|c|c|c|}
\hline Konstanta & Deskripsi & Nilai \\
\hline $\mathrm{V}_{\mathrm{m}}$ & Laju uptake maksimum fitoplankton & 1.5 hari $^{-1}$ \\
\hline $\mathrm{I}_{\mathrm{opt}}$ & $\begin{array}{l}\text { Pemanfaatan cahaya optimum untuk pertumbuhan } \\
\text { fitoplankton }\end{array}$ & $143.9 \mathrm{watt} / \mathrm{m}^{2}$ \\
\hline$\alpha_{1}$ & Koefisien disipasi cahaya pada kolom air laut & $0.04 \mathrm{~m}^{-1}$ \\
\hline$\alpha_{2}$ & Koefisien self-shading fitoplankton & $0.046\left(\mathrm{mmol} \mathrm{N} / \mathrm{m}^{3}\right)^{-1} \mathrm{~m}^{-1}$ \\
\hline $\mathrm{K}_{\mathrm{N} 1}$ & Konstanta half-saturation DIN & $1.0 \mathrm{mmol} \mathrm{N} / \mathrm{m}^{3}$ \\
\hline $\mathrm{A}_{5} \mathrm{D}$ & Laju dekomposisi detritus & 1.03 hari $^{-1}$ \\
\hline $\mathrm{A}_{2} \mathrm{~F}$ & Laju mortalitas spesifik fitoplankton & 0.1 hari $^{-1}$ \\
\hline $\mathrm{A}_{4} \mathrm{Z}$ & Laju mortalitas/ekskresi spefisik zooplankton & 0.145 hari $^{-1}$ \\
\hline $\mathrm{R}_{\mathrm{m}}$ & Laju pemangsaan maksimum oleh zooplankton & 0.52 hari $^{-1}$ \\
\hline$\Lambda$ & Konstanta Ivlev & $0.06\left(\mathrm{mmol} \mathrm{N} / \mathrm{m}^{3}\right)^{-1}$ \\
\hline$\gamma$ & Fraksi pemangsaan maksimum oleh zooplankton & 0.3 \\
\hline
\end{tabular}

Table 1. Constant values used in the model 
Dalam pendekatan selanjutnya, $\mathrm{CO}_{2}$ (aq) dan $\mathrm{H}_{2} \mathrm{CO}_{3}$ (aq) umumnya digabungkan menjadi suatu spesies (hipotesis), yaitu $\left(\mathrm{CO}_{2}{ }^{*}\right.$ (aq) $)$, mengingat keterbatasan dalam membedakan kedua spesies tersebut melalui pendekatan analisis di laboratorium. Selanjutnya persamaan (9), (10) dan (11) dapat dituliskan kembali menjadi:

$$
\begin{aligned}
& \mathrm{CO}_{2(\mathrm{~g})}=\mathrm{CO}_{2}{ }^{*}{ }_{\text {(aq) }} \\
& \mathrm{CO}_{2}{ }^{*}{ }_{(\mathrm{qq})}+\mathrm{H}_{2} \mathrm{O}(\mathrm{l})=\mathrm{H}^{+}{ }_{(\mathrm{aq})}+\mathrm{HCO}_{3-}{ }_{(\mathrm{aq})}
\end{aligned}
$$

Konstanta kesetimbangan kimiawi dari konsentrasi berbagai spesies di atas adalah:

$$
\begin{aligned}
& \mathrm{K}_{0}=\left[\mathrm{CO}_{2}{ }^{*}\right] / \mathrm{f}\left(\mathrm{CO}_{2}\right) \\
& \mathrm{K}_{1}=\left[\mathrm{H}^{+}\right]\left[\mathrm{HCO}_{3-}\right] /\left[\mathrm{CO}_{2}{ }^{*}\right] \\
& \mathrm{K}_{2}=\left[\mathrm{H}^{+}\right]\left[\mathrm{CO}_{3}{ }^{2-}\right] /\left[\mathrm{HCO}_{3^{-}}\right]
\end{aligned}
$$

$\mathrm{f}\left(\mathrm{CO}_{2}\right)$ adalah fugasitas dari karbon dioksida dalam bentuk fasa gas. Konstanta-konstanta kesetimbangan tersebut merupakan fungsi dari suhu, salinitas dan tekanan yang dapat diukur pada kondisi tertentu. Fugasitas tidak sama dengan tekanan parsial, karena menambahkan sifat gas non-ideal.

Namun demikian, konsentrasi dari masingmasing spesies dalam sistem karbonat di laut, tidak dapat diukur secara langsung di laboratorium ataupun lapangan. Tetapi ada empat parameter yang saling berkaitan dalam sistem karbonat di laut yang dapat diukur yaitu total karbon atau total karbon anorganik terlarut (DIC), total alkalinitas (TA), $p \mathrm{CO}_{2}$ dan total konsentrasi ion hidrogen $\left[\mathrm{H}^{+}\right]$.

Perhitungan $p \mathrm{CO}_{2}$ laut didasari oleh termodinamika sistem $\mathrm{CO}_{2}$ tersebut, dimana parameter yang belum diketahui, $\left[\mathrm{CO}_{2} *\right]$, dihitung berdasarkan parameter DIC, TA, dan $\left[\mathrm{H}^{+}\right]$. Total karbon dalam suatu contoh air laut dapat ditulis dalam persamaan berikut:

$\mathrm{DIC}=\left[\mathrm{CO}_{2}{ }^{*}\right]+\left[\mathrm{HCO}_{3}-\right]+\left[\mathrm{CO}_{3}{ }^{2-}\right]$

sedangkan total alkalinitas mengacu pada Dikcson (1981), yaitu:

$$
\begin{aligned}
\mathrm{TA}= & {\left[\mathrm{HCO}_{3}^{-}\right]+2\left[\mathrm{CO}_{3}^{2-}\right]+\left[\mathrm{BOH}_{4}^{-}\right]+\left[\mathrm{OH}^{-}\right] } \\
& +\left[\mathrm{HPO}_{4}^{2-}\right]+2\left[\mathrm{PO}_{4}^{3-}\right]+\left[\mathrm{SiO}(\mathrm{OH})_{3}^{-}\right] \\
& +\left[\mathrm{NH}_{3}\right]+\left[\mathrm{HS}^{-}\right]+\ldots-\left[\mathrm{H}^{+}\right]_{\mathrm{F}}-\left[\mathrm{HSO}_{4}^{-}\right] \\
& -[\mathrm{HF}]-\left[\mathrm{H}_{3} \mathrm{PO}_{4}\right]-\ldots
\end{aligned}
$$

dimana ellipsis adalah sejumlah spesies asam atau basa tertentu yang memiliki kontribusi kecil sehingga dapat diabaikan. $\left[\mathrm{H}^{+}\right]_{\mathrm{F}}$ adalah konsentrasi ion hidrogen bebas. Dengan demikian, setelah DIC dan TA berhasil diketahui maka substitusi fraksi-fraksi DIC (untuk ion bikarbonat dan karbonat) dan fraksi spesies lainnya (dari kesetimbangan konservasi-massa) dalam persamaan TA, akan menghasilkan suatu bentuk persamaan polinimial untuk $\left[\mathrm{H}^{+}\right]$. Dalam OCMIP-2, persamaan polinimial $\left[\mathrm{H}^{+}\right]$dihitung dengan menggunakan metode numerik NewtonRaphson dalam menentukan akar solusinya.

Selanjutnya, fluks pertukaran $\mathrm{CO}_{2}\left(\mathrm{FCO}_{2}\right)$ di lapisan batas udara-laut dapat dihitung berdasarkan perbedaan tekanan parsial $\mathrm{CO}_{2}$ udaralaut, melalui persamaan berikut:

$$
\begin{aligned}
\mathrm{FCO}_{2} & =\mathrm{K}_{\mathrm{w}} \alpha\left(p \mathrm{CO}_{2 \text { laut }}-\mathrm{pCO}_{2 \text { udara }}\right) \\
\mathrm{K}_{\mathrm{w}}= & \left(1.09 \mathrm{~W}-0.333 \mathrm{~W}^{2}\right. \\
& \left.+0.078 \mathrm{~W}^{3}\right)(\mathrm{Sc} / 660)^{-0.5}
\end{aligned}
$$

dimana: $\mathrm{K}_{\mathrm{w}}=$ kecepatan piston yang merupakan fungsi kubik dari kecepatan angin klimatologis (W) (Wanninkhof \& McGillis, 1999), Sc = bilangan Schmidt dan $\alpha=$ daya larut $\mathrm{CO}_{2}$.

Bilangan Schmidt ditentukan berdasarkan hubungan suhu permukaan laut (SST), yaitu persamaan berikut (Wanninkhof, 1992):

$$
\begin{aligned}
\mathrm{Sc}= & 2073.1-125.62 \mathrm{SST} \\
& +3.6276 \mathrm{SST}^{2}-0.043219 \mathrm{SST}^{3}
\end{aligned}
$$

Untuk daya larut $\mathrm{CO}_{2}(\alpha)$, digunakan persamaan Weiss \& Price (1980), berdasarkan fungsi SST dan SSS (salinitas permukaan laut).

$$
\begin{aligned}
& \begin{aligned}
\mathrm{a}= & \exp [-162.8301+218.2968 / \mathrm{tk} 100 \\
& +90.9241 \log \mathrm{tk} 100-1.47696 \mathrm{tk} 1002 \\
& +(\mathrm{SSS}(0.025695-0.025225 \mathrm{tk} 100 \\
& +0.0049867 \mathrm{tk} 1002))]
\end{aligned} \\
& \text { tk }=273,15+\mathrm{SST}\left({ }^{\circ} \mathrm{C}\right) \\
& \text { tk100 }=\text { tk } / 100 \\
& \text { tk1002 }=\text { tk100 } \mathrm{x} \text { tk100 }
\end{aligned}
$$

Keterkaitan antara model ekosistem (aliran nitrogen) dan karbonat laut (aliran karbon) di lapisan air adalah berdasarkan rasio Red-field secara stoikiometrik (carbon linkage, Gambar 1). Perlu dicatat bahwa dalam hubungan ini, perubahan dalam proses biologi (model eksositem) dapat mempengaruhi konsentrasi DIC dan $p \mathrm{CO}_{2}$ laut, melalui produktifitas primer $(\mathrm{N}-$ uptake). Namun, perubahan DIC dan $p \mathrm{CO}_{2}$ laut tidak berdampak terhadap proses biologi. 
Penyebaran DIC secara vertikal di kolom air adalah:

$$
\frac{\partial D I C}{\partial t}=\frac{\partial D I N}{\partial t} r_{C N}
$$

dimana: $\mathrm{r}_{\mathrm{CN}}=$ rasio karbon terhadap nitrogen $(=106 / 16)$. Jadi, pada lapisan permukaan dihitung
$\mathrm{N}$-uptake dengan rasio Red-field dikurangi $\mathrm{CO}_{2}$ flux, sedangkan di lapisan bawahnya dihitung hanya N-uptake dengan rasio Red-field. Kompartemen utama persamaan model ekosistem laut dan kaitannya dengan DIC dan pertukaran gas (fluks) $\mathrm{CO}_{2}$ udara-laut disajikan pada Gambar 1 .

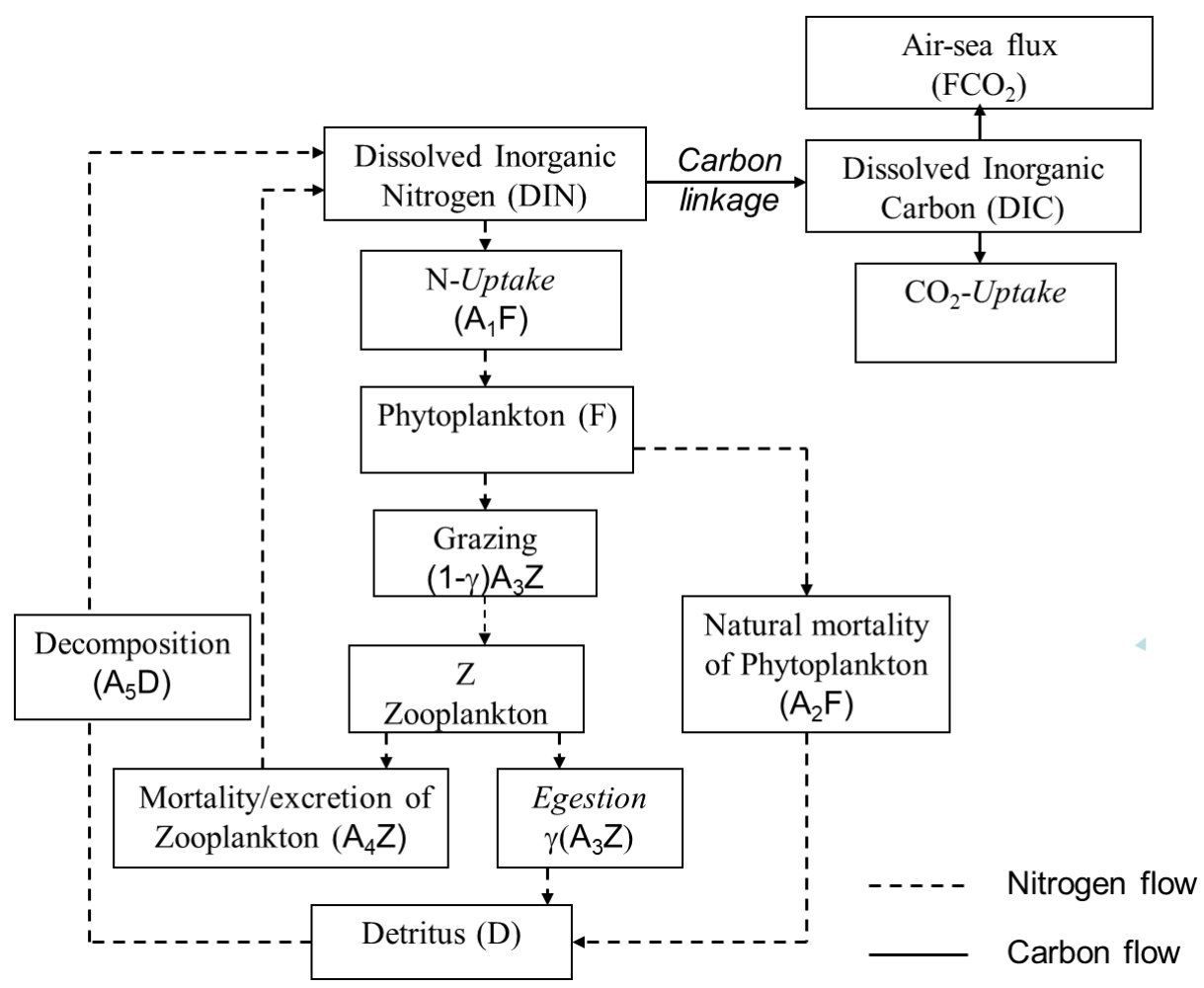

Gambar 1. Kompartemen utama persamaan model ekosistem laut dan kaitannya dengan DIC dan pertukaran gas (fluks) $\mathrm{CO}_{2}$ udara-laut.

Figure 1. The main compartments of the marine ecosystem model equations and their relationship to DIC and air-sea $\mathrm{CO}_{2}$ gas exchange.

Nilai awal yang digunakan untuk kompartemen ekosistem adalah $0,1 \mathrm{mmol} / \mathrm{m}^{3}$, kecuali DIN yang nilainya lebih besar $(0,3$ $\left.\mathrm{mmol} / \mathrm{m}^{3}\right)$. Nilai-nilai ini diadopsi berdasarkan percobaan model (tunning model) dan nilainya sama untuk seluruh kedalaman. Berkaitan dengan perhitungan sistem karbonat laut, beberapa nilai parameter tetap (fixed or diagnostic parameters) yang digunakan adalah: nilai rerata tahunan silikat $=9,87 \mathrm{mmol} / \mathrm{m}^{3}$ (Levitus94) dan total alkalinitas = $2087 \mathrm{mmol} / \mathrm{kg}$ (Goyet et al., 2000). Selain itu terdapat beberapa parameter yang merupakan kondisi umum di Laut Jawa, yaitu SST $=28,3^{\circ} \mathrm{C}$, $\mathrm{SSS}=34,6 \mathrm{psu}$, dan kisaran $\mathrm{pH}=6,90-8,72$.

Jumlah grid model vertikal adalah 21 sigma layer pada dengan kedalaman air $39 \mathrm{~m}$, dimana resolusinya sama dengan model hidrodinamika 3dimensi Laut Jawa (Koropitan \& Ikeda, 2008) yang memiliki resolusi tinggi di dekat permukaan dan dasar, yaitu: $\sigma=0.0,-0.009,-0.018,-0.036$, -
$0.071,-0.143,-0,214,-0.286,-0.357,-0.429,-0.5$, $-0.571,-0.643,-0.714,-0.786,-0.857,-0.929$, $0.964,-0.982,-0.991,-1.0$. Secara khusus untuk perhitungan fluks $\mathrm{CO}_{2}$ di lapisan udara-laut, maka diberikan berbagai nilai konsentrasi $\mathrm{CO}_{2} \mathrm{di}$ atmosfer untuk mempelajari respon dari sistem biogeokimia laut. Nilai-nilai konsentrasi $\mathrm{CO}_{2}$ adalah mewakili kondisi tahun 2000 (360 ppm) dan saat kebakaran hutan di Kalimantan yang terjadi pada kurun waktu antara September sampai Oktober 2002 (460 ppm), yang bertepatan dengan kejadian El Niño (Hirano et al., 2004). Dalam hal ini diasumsikan bahwa $\mathrm{CO}_{2}$ yang dilepaskan akibat kebakaran hutan di daratan (Pulau Kalimantan) menyebar merata sampai di sekitar daerah model (pesisir selatan Kalimantan). Untuk skenario perubahan iklim, penelitian ini menggunakan skenario terbaru SSP (the shared socio-economic pathway), dimana konsentrasi $\mathrm{CO}_{2}$ di atmosfer untuk skenario tertinggi mencapai 1135,2 ppm pada tahun 2100 
(Meinshausen et al., 2020). Penerapan model 1dimensi vertikal juga berdampak pada hilangnya pengaruh masukan dari sungai ataupun adveksi perairan disekitarnya, sehingga proses biologi dan sistem karbonat laut yang terjadi di kolom air merupakan sistem tertutup. Dengan demikian, simulasi ini terfokus kepada interaksi proses biologi perairan laut dan fluks $\mathrm{CO}_{2}$ di lapisan udara-air termasuk dampak fluks antropogenik $\mathrm{CO}_{2}$ di atmosfer (akibat kebakaran hutan).

Simulasi dilakukan untuk desain 4 periode yang berbeda sesuai dengan konsentrasi $\mathrm{CO}_{2}$ di atmosfer, yaitu Februari dan Oktober 2000, saat kebakaran hutan Oktober 2002 dan Oktober 2100 (skenario SSP tertinggi). Jadi, proses perhitungan dilakukan terpisah untuk masing-masing periode model, dimana langkah waktu numerik yang digunakan adalah 1 jam, dan lama perhitungan numerik mencapai 1060 hari untuk mencapai kondisi tunak (steady state). Nilai awal untuk DIC menggunakan hasil model nilai rerata musiman DJF (Desember, Januari dan Februari) dan SON (September, Oktober, November), menggunakan hasil model Goyet et al. (2000) di sekitar daerah model Laut Jawa yang bervariasi secara kedalaman. Intensitas cahaya permukaan dan kecepatan angin menggunakan reanalysis data pada kedua bulan tersebut, dimana intensitas cahaya permukaan 184 dan 220 watt $/ \mathrm{m}^{2}$ untuk bulan Februari dan Oktober (Oberhuber, 1998), kecepatan angin 4,11 dan 3,65 m/detik untuk bulan Februari dan Oktober (Hellerman \& Rosenstein, 1983), serta input proses percampuran secara vertikal (vertical eddy diffusivity) yang dipengaruhi oleh pasut dan angin bulan Februari dan Oktober dari hasil model (Koropitan \& Ikeda, 2016).

\section{Hasil}

Hasil simulasi untuk proses biologi dan aliran nitrogen dalam sistem tertutup diperlihatkan pada Gambar 2. Sebagai catatan bahwa Gambar 2 merupakan hasil simulasi pada Februari dan Oktober 2000. Perbedaan kedua bulan ini, baik stok maupun fluks tidak terlalu signifikan, sebagai konsekuensi sistem tertutup (tidak ada input dari daratan). Hasil perhitungan proses biologi dan aliran nitrogen untuk Oktober 2000 menunjukkan hasil yang sama untuk Oktober 2002 (saat kebakaran hutan) dan Oktober 2100 (skenario SSP tertinggi), karena fluks $\mathrm{CO}_{2}$ tidak berdampak terhadap proses biologi dalam pemodelan ini. Hasil perhitungan menunjukkan bahwa stok nitrogen dalam bentuk DIN memiliki konsentrasi terbesar dibanding dengan kompartemen lainnya ( $\mathrm{F}, \mathrm{Z}$ dan $\mathrm{D})$. Fluks terbesar dalam aliran nitrogen ini adalah $\mathrm{N}$-upatke, kemudian diikuti oleh fluks dari mortalitas/ekskresi dan proses dekomposisi, sehingga kedua fluks ini memiliki andil dalam suplai DIN di kolom air.

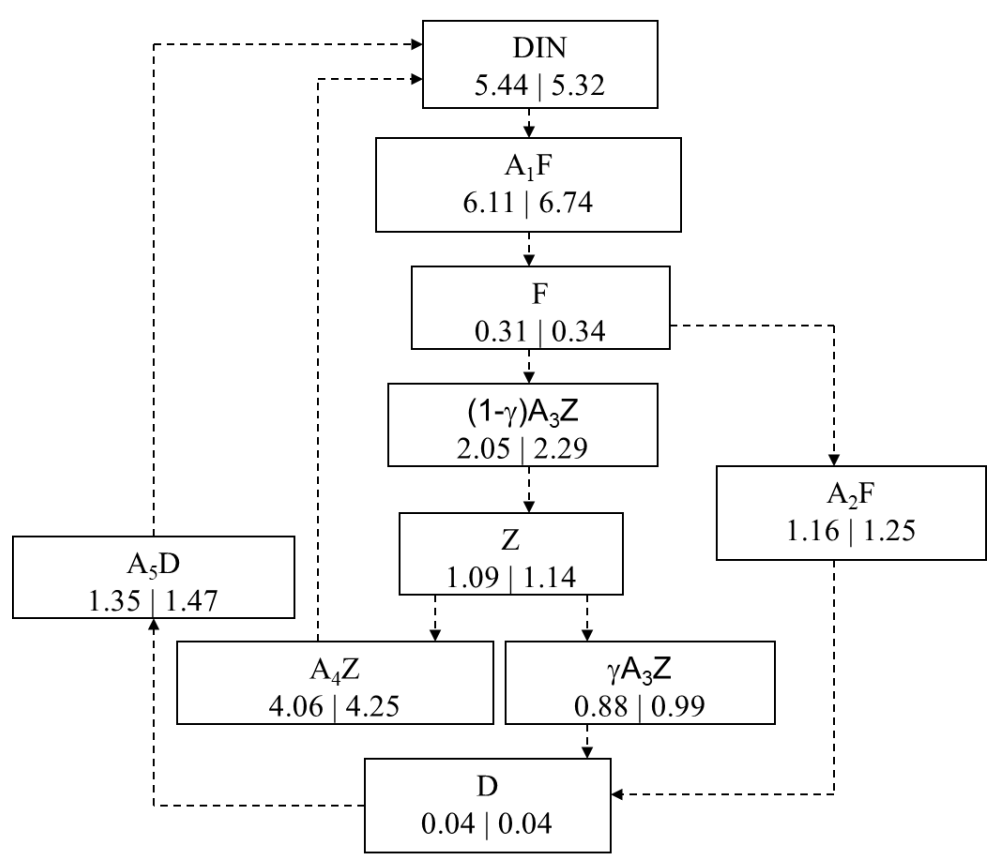

Gambar 2. Stok $\left(\mathrm{mmolN} / \mathrm{m}^{3}\right)$ dan fluks ( $\mathrm{mmolN} / \mathrm{m}^{2} /$ hari) nitrogen untuk masing-masing kompartemen ekosistem saat Februari 2000 (sisi kiri) dan Oktober 2000 ( sisi kanan).

Figure 2. Nitrogen stock $\left(\mathrm{mmolN} / \mathrm{m}^{3}\right)$ and flux $\left(\mathrm{mmolN} / \mathrm{m}^{2} /\right.$ day) for each ecosystem compartment during February 2000 (left side) and October 2000 (right side). 
Gambar 2 memperlihatkan bahwa penggunaan nutrien untuk pertumbuhan fitoplankton (N-uptake) adalah sebesar 84,9$88,5 \%$ dari total fluks input nutrien (dekomposisi dan mortalitas/ekskresi Z). Transfer energi dalam hal ini tidak mencapai $100 \%$, akibat beberapa faktor dalam perhitungan $\mathrm{N}$-uptake (persamaan 5). Bila nilai stok DIN dan F pada Gambar 2, serta nilai intensitas cahaya dipermukaan disubstitusikan dalam persamaan 5, maka diperoleh nilai minimum dari suku [DIN / $(\mathrm{KN}+$ DIN)]. Dengan demikian, suku ini merupakan faktor pembatas dalam menentukan besaran $\mathrm{N}$ uptake atau lebih fokus lagi adalah konstanta halfsaturation DIN $\left(\mathrm{K}_{\mathrm{N}}\right)$. Konstanta ini menggambarkan kemampuan relatif dari fitoplankton untuk menggunakan nutrien pada level rendah. Hasil eksperimen Eppley et al. (1969) pada temperatur konstant $\left(20^{\circ} \mathrm{C}\right)$ memperlihatkan bahwa $\mathrm{K}_{\mathrm{N}}$ bervariasi secara proporsional dengan ukuran sel fitoplankton laut, yaitu $\leq 0,5 \mu \mathrm{M}$ sampai $>5 \mu \mathrm{M}$ untuk ukuran sel fitoplankton yang kecil sampai besar.

Selain itu, persamaan 5 memiliki unsur non-linier yang dikontrol oleh DIN dan intensitas cahaya. Pada proses di alam, pengaruh daratan (sungai dan air tanah), serta adveksi akan mengontrol penyebaran DIN di kolom air. Untuk kasus laut dangkal seperti Laut Jawa, potensi fluks di sedimen dasar juga ikut berpengaruh dalam suplai DIN di kolom air. Namun, intensitas cahaya untuk perairan Laut Jawa (tropis) cenderung sama untuk sepanjang tahun, sehingga pengaruhnya dapat diabaikan. Dengan demikian, parameter-paramter inilah yang menentukan produktifitas primer $\left(\mathrm{A}_{1} \mathrm{~F}\right)$, dimana nilainya dapat lebih besar atau sedikit dibanding dekomposisi detritus dan mortalitas/eksresi Z.

Keterkaitan $\mathrm{N}$-uptake dan $\mathrm{CO}_{2}$-uptake oleh proses biologi dihitung dengan menggunakan rasio Red-field. Hasil perhitungan DIC, fluks karbon udara-laut dan $\mathrm{CO}_{2}$-uptake sebelum kebakaran hutan (Februari dan Oktober 2000), saat kebakaran hutan Oktober 2002, dan skenario tertinggi SSP Oktober 2100 diperlihatkan pada Gambar 3. Nilai $\mathrm{CO}_{2}$-uptake memiliki nilai yang berbeda untuk Februari dan Oktober 2000 sebelum kebakaran hutan (Gambar 3a). Perbedaan ini ditentukan oleh stok DIC, yang dipengaruhi oleh pertukaran $\mathrm{CO}_{2}$ di lapisan udara-laut $\left(\mathrm{FCO}_{2}\right)$. Stok DIC pada Februari 2000 lebih kecil dibanding pada Oktober 2000 sebelum kebakaran hutan dan terus meningkat seiring dengan meningkatnya konsentrasi $\mathrm{CO}_{2}$ di atmosfer saat kebakaran hutan dan skenario tahun 2100.

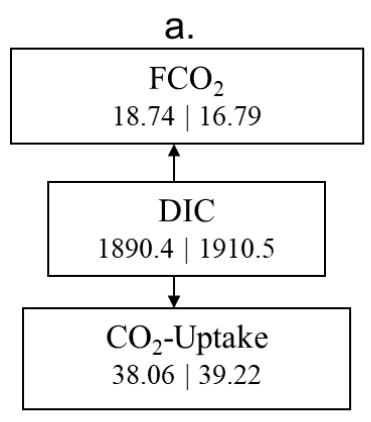

$\mathrm{pH}=7.8279 \mid 7.7822$

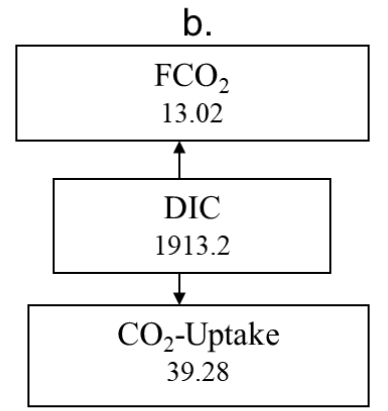

$\mathrm{pH}=7.7758$

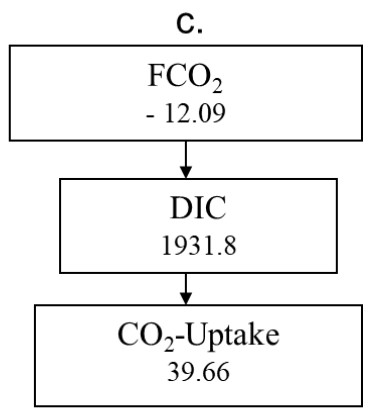

$\mathrm{pH}=7.7312$

Gambar 3. Stok ( $\mu \mathrm{molC} / \mathrm{kg}$ ) dan fluks ( $\mathrm{mmolC} / \mathrm{m}^{2} /$ hari) karbon udara-laut sebelum kebakaran hutan (a) saat Februari 2000 (sebelah kiri) dan Oktober 2000 (sebelah kanan), saat kebakaran hutan Oktober 2002 (b), dan skenario tertinggi SSP Oktober 2100 (c).

Figure 3. Air-sea carbon stocks ( $\mu \mathrm{molC} / \mathrm{kg}$ ) and fluxes ( $\mathrm{mmolC} / \mathrm{m}^{2} /$ day) before forest fires (a) in February 2000 (left side) and October 2000 (right side), during forest fire October 2002 (b), and the highest SSP scenario in October 2100 (c).

Selanjutnya, perbedaan $\mathrm{FCO}_{2}$ antara Februari dan Oktober 2000 sebelum kebakaran hutan berkaitan dengan kecepatan piston $\left(\mathrm{K}_{\mathrm{w}}\right)$. Kecepatan piston atau dapat disebutkan koefisien laju pertukaran gas sangat ditentukan oleh turbulensi di sekitar permukaan air, dimana pada percobaan di laboratorium memiliki kaitan erat 156 dengan kecepatan angin, seperti yang diperlihatkan pada persamaan 21. Jadi, semakin besar kecepatan angin maka semakin besar pula pertukaran gas di lapisan permukaan air. Data yang digunakan dalam perhitungan ini menunjukkan bahwa pada Februari 2000 yang dipengaruhi muson barat laut memiliki kecepatan 
angin yang lebih besar dibanding Oktober 2000 (transisi ke muson barat laut), sehingga menghasilkan $\mathrm{FCO}_{2}$ pada Februari 2000 lebih besar dibanding Oktober 2000.

Gambar 3a dan $\mathrm{b}$ memperlihatkan nilai positif pada $\mathrm{FCO}_{2}$, menunjukkan bahwa perairan ini berperan sebagai pelepas karbon. Faktor utama yang sangat menentukan dalam hal ini adalah SST yang relatif tinggi untuk perairan tropis. SST dalam perhitungan sistem karbonat laut sangat berperan dalam menentukan daya larut $\mathrm{CO}_{2}(\alpha)$, seperti yang diperlihatkan pada persamaan 23. Proses ini dikenal dengan istilah solubility pump atau pompa daya larut. Hasil simulasi ini menunjukkan bahwa proses biologi $\left(\mathrm{CO}_{2}\right.$-uptake $)$ tidak berdampak signifikan dalam menentukan kondisi saturasi konsentrasi $\mathrm{CO}_{2}$ di permukaan air. Hal lain yang menarik adalah kondisi saat kebakaran hutan dapat menurunkan nilai $\mathrm{FCO}_{2}$ (Gambar 3b). Kenaikan konsentrasi $\mathrm{CO}_{2}$ di atmosfer saat kebakaran hutan telah merubah kesetimbangan tekanan parsial, namun nilai $\mathrm{FCO}_{2}$ masih tetap positif atau sebagai pelepas karbon ke udara. Perubahan kesetimbangan tekanan parsial berdampak pada penurunan karbon yang dilepaskan ke atmosfer. Bahkan pada kondisi ekstrim, bila konsentrasi $\mathrm{CO}_{2}$ di atmosfer naik menjadi sebesar 1135,2 ppm (sesuai dengan skenario SSP tertinggi untuk tahun 2100), maka nilai $\mathrm{FCO}_{2}$ akan berubah menjadi negatif atau merupakan penyerap karbon, yaitu - 12,09 mmol $\mathrm{C} / \mathrm{m}^{2} /$ hari (Gambar 3c). Gambar 3 juga memperlihatkan hasil perhitungan model untuk $\mathrm{pH}$, dimana pada studi ini menunjukkan bahwa untuk Oktober sebelum dan saat kebakaran hutan, nilai $\mathrm{pH}$ turun sebesar 0,0064 dan pada skenario SSP tertinggi Oktober 2100 akan turun sebesar 0,051 . Hasil perhitungan nilai $\mathrm{pH}$ memperlihatkan kondisi berbanding terbalik dengan stok DIC.

\section{Pembahasan}

Hasil penelitian ini memperlihatkan konsistensi dengan teori yang dibangun sebelumnya, sebagaimana diuraikan dalam penelitian Gruber et al. (2009), dimana secara alami dan kontemporer, perairan laut tropis akan berfungsi sebagai pelepas $\mathrm{CO}_{2}$ ke atmosfer. Hasil simulasi penelitian ini memperlihatkan bahwa tren kenaikan $\mathrm{CO}_{2}$ di atmosfer akan mempengaruhi fluks pertukaran $\mathrm{CO}_{2}$ di lapisan udara-laut. Dalam hal ini, perairan tropis Laut Jawa memiliki pola fluks sebagaimana halnya perairan tropis lainnya. Semakin tinggi $\mathrm{CO}_{2}$ di atmosfer, maka semakin rendah pelepasan $\mathrm{CO}_{2}$ dari perairan laut tropis.
Dengan kata lain, pada situasi $\mathrm{CO}_{2}$ di atmosfer yang (relatif) rendah, maka perairan laut tropis akan melepas banyak karbon kontemporer ke udara, atau sebaliknya pada saat kenaikan $\mathrm{CO}_{2}$ di atmosfer maka perairan laut tropis akan melepas sedikit. Selisih karbon laut saat melepas banyak $\left(\mathrm{CO}_{2}\right.$ di atmosfer rendah) dan saat melepas sedikit $\left(\mathrm{CO}_{2}\right.$ di atmosfer tinggi) adalah karbon antropogenik yang diserap oleh laut tropis. Hal ini yang terlihat dari hasil simulasi ini, sebelum dan saat kebakaran hutan dimana fluks pertukaran $\mathrm{CO}_{2}$ udara-laut berkurang dari 16,79-18,74 mmol $\mathrm{C} / \mathrm{m}^{2} /$ hari menjadi $13,02 \mathrm{mmol} \mathrm{C} / \mathrm{m}^{2} /$ hari.

Hal ini berbeda memang di perairan dingin, dimana fluks pertukaran $\mathrm{CO}_{2}$ di lapisan udara-laut kontemporer dan alami berfungsi sebagai penyerap $\mathrm{CO}_{2}$ di atmosfer. Semakin tinggi $\mathrm{CO}_{2}$ di atmosfer, maka semakin tinggi pula penyerapan $\mathrm{CO}_{2}$ dari perairan laut dingin. Dengan kata lain, pada situasi $\mathrm{CO}_{2}$ di atmosfer yang (relatif) rendah, maka perairan laut dingin akan menyerap sedikit karbon kontemporer dari atmosfer, atau sebaliknya pada saat kenaikan $\mathrm{CO}_{2}$ di atmosfer maka perairan laut dingin akan menyerap banyak. Selisih karbon laut saat menyerap sedikit $\left(\mathrm{CO}_{2}\right.$ di atmosfer rendah) dan saat menyerap banyak $\left(\mathrm{CO}_{2}\right.$ di atmosfer tinggi) adalah karbon antropogenik yang diserap oleh laut dingin.

Penelitian ini juga memperlihatkan adanya perubahan kesetimbangan di perairan tropis Laut Jawa saat konsentrasi $\mathrm{CO}_{2}$ di atmosfer terus naik menjadi 1135,2 ppm pada tahun 2100 (skenario SSP tertinggi). Dalam hal ini fluks pertukaran $\mathrm{CO}_{2}$ di lapisan udara-laut kontemporer berubah dari pelepas menjadi penyerap sebesar 12,09 $\mathrm{mmol} \mathrm{C} / \mathrm{m}^{2} /$ hari. Dengan demikian, jika nilai alami relatif tetap, maka semakin banyak karbon antropogenik yang diserap oleh laut tropis. Ini konsisten dengan semakin banyak juga kenaikan $\mathrm{CO}_{2}$ antropogenik di atmosfer. Sebagai pembanding dalam penelitian di samudera, kajian Gruber et al. (2009) tentang pertukaran karbon neto udara-laut antropogenik, alami dan kontemporer ini memperlihatkan bahwa perairan samudera telah berubah fungsi dari pelepas (masa pra-industri) menjadi penyerap pada masa ini. Jadi memang ada perubahan kesetimbangan untuk perairan samudera. Penelitian terbaru Gruber et al. (2019) melaporkan bahwa tidak ada jaminan perairan samudera akan terus menyerap $\mathrm{CO}_{2}$ antropogenik di atmosfer.

Persoalan kebakaran hutan di Indonesia dan emisi antropogenik $\mathrm{CO}_{2}$ di atmosfer telah menjadi perhatian dunia. Laporan Tacconi \& Muttaqin (2019) menyebutkan Indonesia sebagai penghasil 
emisi gas rumah kaca terbesar kedua dari hutan setelah Brasil, tetapi menjadi penghasil emisi terbesar dari hutan dalam beberapa tahun ketika mengalami kebakaran hutan dan gambut yang signifikan. Aminah et al. (2020) telah membahas semua kemungkinan celah dalam sistem yang mungkin berkontribusi pada berlanjutnya kebakaran hutan. Penelitian ini memang belum memasukan dampak asidifikasi laut terhadap biota di Laut Jawa, namun tidak tertutup kemungkinan emisi $\mathrm{CO}_{2}$ dari kebakaran hutan serta pengaruh daratan akan memperparah asidifikasi laut di lokasi studi.

Konsekuensi dari penyerapan karbon di atmosfer oleh laut menimbulkan permasalahan baru, yaitu asidifikasi atau pengasaman laut. Seperti yang disinggung sebelumnya, bahwa ada empat parameter yang saling berkaitan dalam sistem karbonat di laut, yaitu total karbon atau total karbon anorganik terlarut (DIC), total alkalinitas (TA), $p \mathrm{CO}_{2}$ laut dan total konsentrasi ion hidrogen $\left[\mathrm{H}^{+}\right]$. Parameter terakhir ini berkaitan dengan indikator keasaman atau $\mathrm{pH}$. Hasil penelitian ini memperlihatkan bahwa untuk Oktober sebelum dan saat kebakaran hutan, nilai $\mathrm{pH}$ turun sebesar 0,0064. Pada skenario SSP tertinggi Oktober $2100 \mathrm{pH}$ akan turun sebesar 0,051 dibanding Oktober 2000 sebelum kebakaran hutan, atau tren penurunan $\mathrm{pH} 0,00052 /$ tahun. Hasil pengukuran tingkat pengasaman di perairan Warm Pool Pasifik barat tropis, menunjukkan angka tren penurunan $\mathrm{pH} 0,0013 \pm 0,0001 /$ tahun untuk periode 1985-2016 (Ishii et al., 2020).

Dalam hal skenario perubahan iklim, memang menunjukkan angka yang berbeda, tergantung skenario yang digunakan. Hasil rekonstruksi model dan pengukuran lapangan memperlihatkan bahwa $\mathrm{pH}$ (total) permukaan laut rata-rata global menurun $0,11 \pm 0,03$ dari tahun 1770 sampai 2000, sementara untuk skenario bussines as usual IPCC RCP8.5, pH (total) permukaan laut rata-rata global tahunan akan berkurang sebesar $0,33 \pm 0,04$ unit dan kapasitas penyangga lautan akan berkurang dengan rata-rata 34\% dari tahun 2000 hingga 2100 (Jiang et al., 2019). Proyeksi model dengan skenario terbaru IPCC menunjukkan penurunan $\mathrm{pH}$ permukaan $0,44 \pm 0,005$ untuk skenario emisi tinggi (SSP58.5) untuk nilai rata-rata tahun 2080-2099 relatif terhadap tahun 1870-1899, sementara untuk skenario rendah emisi dan mitigasi tinggi (SSP12.6) penurunan $\mathrm{pH}$ permukaan $0,16 \pm 0,002$ (Kwiatkowski et al., 2020).

\section{Kesimpulan}

Hasil simulasi ini menyimpulkan bahwa SST yang relatif tinggi merupakan parameter dominan yang menentukan pertukaran $\mathrm{CO}_{2}$ udaralaut, sehingga Laut Jawa sebagai perairan tropis berfungsi sebagai pelepas karbon di atmosfer. Hasil perhitungan model juga dapat mewakili kondisi alami sebelum fluks antropogenik terjadi (masa pra-industri). Hasil model memperlihatkan bahwa kenaikan konsentrasi $\mathrm{CO}_{2}$ di atmosfer saat kebakaran hutan akan mempengaruhi kesetimbangan tekanan parsial di lapisan udaralaut, sehingga fluks pelepasan karbon ke atmosfer berkurang. Pendekatan model 1-dimensi memang terbatas sifatnya, namun keuntungan dari model ini adalah mampu melakukan pendugaan secara cepat perubahan ekosistem laut di masa depan akibat dampak kenaikan $\mathrm{CO}_{2}$ di atmosfer. Perubahan dari kondisi awal sampai kondisi antropogenik kenaikan $\mathrm{CO}_{2}$ atmosfer dapat diuraikan dalam simulasi model karbonat laut ini yang digabung dengan model hidrodinamika dan ekosistem laut. Pendekatan 3-dimensi tentunya membutuhkan waktu komputasi lebih lama, jika fokus bahasan terkait kolom kedalaman air dari permukaan air sampai sedimen serta pengaruh sungai yang menyebar di dalamnya.

\section{Persantunan}

Penelitian ini dilakukan di Big Data and Ocean Modeling (BiOM) Laboratory, Departemen Ilmu dan Teknologi Kelautan, Fakultas Perikanan dan Ilmu Kelautan, Institut Pertanian Bogor.

\section{Daftar Pustaka}

Aminah, Krah, C. Y., \& Perdinan. (2020). Forest fires and management efforts in Indonesia (a review). IOP Conference Series: Earth and Environmental Science, 504, 012013.

Denman, K. L., \& Peña, M. A. (1999). A coupled 1-D biological/physical model of the northeast subartic Pasific Ocean with iron limitation, Deep Sea Research Part II, 46, 2877-2908.

Dickson, A. G., Sabine, C. L., \& Christian, J. R. (2007). Guide to best practices for ocean $\mathrm{CO}_{2}$ measurements, PICES Special Publication 3, pp. 191.

Eppley, R. W., Rogers, J. N., \& McCarthy, J. J. (1969). Half-Saturation Constants for Uptake of Nitrate and Ammonium by 
Marine Phytoplankton, Limnology and Oceanography, 14(6), 912-920.

Friedlingstein, P., O'Sullivan, M., Jones, M. W., Andrew, R. M., Hauck, J., Olsen, A., Peters, G. P., Peters, W., Pongratz, J., Sitch, S., Le Quéré, C., Canadell, J. G., Ciais, P., Jackson, R. B., Alin, S., Aragão, L. O. C., Arneth, A., Arora, V., Bates, N. R., Becker, M., Benoit-Cattin, A., Bittig, H. C., Bopp, L., Bultan, S., Chandra, N., Chevallier, F., Chini, L. P., Evans, W., Florentie, L., Forster, P. M., Gasser, T., Gehlen, M., Gilfillan, D., Gkritzalis, T., Gregor, L., Gruber, N., Harris, I., Hartung, K., Haverd, V., Houghton, R. A., Ilyina, T., Jain, A. K., Joetzjer, E., Kadono, K., Kato, E., Kitidis, V., Korsbakken, J. I., Landschützer, P., Lefèvre, N., Lenton, A., Lienert, S., Liu, Z., Lombardozzi, D., Marland, G., Metzl, N., Munro, D. R., Nabel, J. E. M. S., Nakaoka, S.-I., Niwa, Y., O'Brien, K., Ono, T., Palmer, P. I., Pierrot, D., Poulter, B., Resplandy, L., Robertson, E., Rödenbeck, C., Schwinger, J., Séférian, R., Skjelvan, I., Smith, A. J. P., Sutton, A. J., Tanhua, T., Tans, P. T., Tian, H., Tilbrook, B., van der Werf, G., Vuichard, N., Walker, A. P., Wanninkhof, R., Watson, A. J., Willis, D., Wiltshire, A. J., Yuan, W., Yue, X., \& Zaehle, S. (2020). Global Carbon Budget 2020. Earth System Science Data, 12, 3269-3340.

Goyet, C., Healy, R. J., \& Ryan, J., P. (2000). Global distribution of total inorganic carbon and total alkalinity below the deepest winter mixed layer depths. ORNL/CDIAC-127, NDP-076. Carbon Dioxide Information Analysis Center, in Oak Ridge National Laboratory, U.S. Department of Energy, Oak Ridge, Tennessee.

Gruber, N., Gloor, M., Fletcher, S. E. M., Doney, S. C., Dutkiewicz, S., Follows, M. J., Gerber, M., Jacobson, A. R., Joos, F., Lindsay, K., Menemenlis, D., Mouchet, A., Müller, S. A., Sarmiento, J. L., \& T. Takahashi. (2009). Oceanic sources, sinks, and transport of atmospheric $\mathrm{CO}_{2}$. Global Biogeochemical Cycles, 23, GB1005.

Gruber, N., Clemen, D., Carter, B. R., Feely, R. A., Heuven, S. V., Hoppema, M., Ishii, M., Key, R. M., Kozyr, A., Lauvset, S. K., Monaco, C. L., Mathis, J. T., Murata, A., Olsen, A., Perez, F. F., Sabine, C. L., Tanhua, T., \& Wanninkhof, R. (2019).
The oceanic sink for anthropogenic $\mathrm{CO}_{2}$ from 1994 to 2007. Science, 363, 11931199.

Hamzah, F., Agustiadi, T., Susanto, R. D., Wei, Z., Guo, L., Cao, Z., \& Dai, M. (2020). Dynamics of the Carbonate System in the Western Indonmesian Seas During the Southeast Monsoon. Journal of Geophysical Research: Oceans, 125, e2018JC014912.

Hauck, J., Zeising, M., Le Quéré, C., Gruber, N., Bakker, D. C. E., Bopp, L., Chau, T. T. T., Gürses, Ö., Ilyina, T., Landschützer, P., Lenton, A., Resplandy, L., Rödenbeck, C., Schwinger, J., \& Séférian, R. (2020). Consistency and Challenges in the Ocean Carbon Sink Estimate for the Global Carbon Budget. Frontiers in Marine Science, 7, 571720.

Hellerman, S., \& Rosenstein. M. (1983). Normal monthly wind stress over the world ocean with error estimates, Journal of Physical Oceanography, 13, 1093-1104.

Hirano, T., Segah, H., Limin, S., June, T., Tuah,J. S., Kitso, Hirata, R., \& Osaki, M. (2004). The El Nino drought and its consequent peatland fires changed $\mathrm{CO}_{2}$ exchange of a tropical peat swamp forest in Central Kalimantan, Indonesia, in Environmental Conservation and Land Use Management of Wetland Ecosystem in Southeast Asia. Annual Report April 2003 - March 2004. JSPS Core University Program between Hokkaido University, Japan and Research Center for Biology, LIPI-Indonesia.

Huang, T. H., Chen, C. T. A., Tseng, H. C., Lou, J. Y., Wang, S. L., Yang, L., Kandasamy, S., Gao, X., Wang, J. T., Aldrian, E., Jacinto, G. S., Anshari, G. Z., Sompongchaiyakul, P., \& Wang, B. J. (2017). Riverine carbon fluxes to the South China Sea. Journal of Geophysical Research: Biogeoscience, 122, 1239-1259.

Huijnen, V., Wooster, M. J., Kaiser, J. W., Gaveau, D. L. A., Flemming, J., Parrington, M., Inness, A., Murdiyarso, D., Main, B., \& van Weele, M. (2016). Fire carbon emissions over maritime southeast Asia in 2015 largest since 1997. Scientific Reports, 6, 26886.

IPCC, 2021. Summary for Policymakers. In: Climate Change 2021: The Physical Science Basis. Contribution of Working Group I to the Sixth Assessment Report of the Intergovernmental Panel on Climate 
Change [Masson-Delmotte, V., P. Zhai, A. Pirani, S. L. Connors, C. Péan, S. Berger, N. Caud, Y. Chen, L. Goldfarb, M. I. Gomis, M. Huang, K. Leitzell, E. Lonnoy, J.B.R. Matthews, T. K. Maycock, T. Waterfield, O. Yelekçi, R. Yu \& B. Zhou (eds.)]. Cambridge University Press. In Press.

Ishii, M., Rodgers, K. B., Inoue, H. Y., Toyama, K., Sasano, D., Kosugi, N., Ono, H., Enyo, K., Nakano, T., Iudicone, D., Blanke, B., Aumont, O., \& Feely. R. A. (2020). Ocean Acidification From Below in the Tropical Pacific. Global Biogeochemical Cycles, 34(8), 24 e2019GB006368.

Jiang, L.-Q., Carter, B. R., Feely, R.A., Lauvset, S. K., \& Olsen, A. (2019). Surface ocean $\mathrm{pH}$ and buffer capacity: past, present and future. Scientific Reports, 9(1), 18624.

Kartadikaria, A. R., Watanabe, A., Nadaoka, K., Adi, N. S., Prayitno, H. B., Suharsono, S., Muchtar, M., Triyulianti, I., Setiawan, A., Suratno, S., \& Khasanah, E. N. (2015). $\mathrm{CO}_{2}$ sink/source characteristics in the tropical Indonesian seas. Journal of Geophysical Research: Oceans, 120(12).

Koropitan, A. F., \& Ikeda, M. (2008). Threedimensional modelling of tidal circulation and mixing over the Java Sea, Journal of Oceanography, 64(1), 61-80.

Koropitan, A. F., \& Ikeda, M. (2016). Influences of physical processes and anthropogenic influx on biogeochemical cycle in the Java Sea: numerical model experiment. Procedia Environmental Sciences, 33, 532-552.

Kwiatkowski, L., Torres, O., Bopp, L., Aumont, O., Chamberlain, M., Christian, J. R., Dunne, J. P., Gehlen, M., Ilyina, T., John, J. G., Lenton, A., Li, H., Lovenduski, N. S., Orr, J. C., Palmieri, J., Santana-Falcón, Y., Schwinger, J., Séférian, R., Stock, C. A., Tagliabue, A., Takano, Y., Tjiputra, J., Toyama, K., Tsujino, H., Watanabe, M., Yamamoto, A., Yool, A., \& Ziehn, T. (2020). Twenty-first century ocean warming, acidification, deoxygenation, and upper-ocean nutrient and primary production decline from CMIP6 model projections. Biogeosciences, 17, 34393470.

Laruelle, G. G., Cai, W.-J., Hu, X., Gruber, N., Mackenzie, F. T., \& Regnier, P. (2018). Continental shelves as a variable but increasing global sink for atmospheric carbon dioxide. Nature Communications, 9(1), 454.

Meinshausen, M., Nicholls, Z. R. J., Lewis, J., Gidden, M. J., Vogel, E., Freund, M., Beyerle, U., Gessner, C., Nauels, A., Bauer, N., Canadell, J. G., Daniel, J. S., John, A., Krummel, P. B., Luderer, G., Meinshausen, N., Montzka, S. A., Rayner, P. J., Reimann, S., Smith, S. J., van den Berg, M., Velders, G. J. M., Vollmer, M. K., \& Wang, R. H. J. (2020). The shared socio-economic pathway (SSP) greenhouse gas concentrations and their extensions to 2500. Geoscientific Model Development, 13, 3571-3605

Mikaloff Fletcher, S. E., Gruber, N., Jacobson, A. R., Doney, S. C., Dutkiewicz, S., Gerber, M., $\quad$ Follows, M., Joos, F., Lindsay, K., Menemenlis, D., Mouchet, A., Müller, S. A., \& Sarmiento, J. L. (2006). Inverse estimates of anthropogenic $\mathrm{CO}_{2}$ uptake, transport, and storage by the ocean. Global Biogeochemical Cycles, 20, GB2002.

Oberhuber, J. M. (1998). An Atlas Based on 'COADS' Data Set, number 15.

Orr, J. C. (2002). Global ocean storage of anthropogenic carbon (GOSAC), final report, in EC Environ. Clim. Programme, Inst. Pierre-Simon Laplace, Paris.

Orr, J. C., Maier-Reimer, E., Mikolajewicz, U., Monfray, P., Sarmiento, J. L., Toggweiler J. R., Taylor, N. K., Palmer, J., Gruber, N., Sabine, C. L., Le Quéré, C., Key, R. M., \& Boutin, J. (2001). Estimates of anthropogenic carbon uptake from four three-dimensional global ocean models. Global Biogeochemical Cycles, 15, 43-60.

Roobaert, A., Laruelle, G. G., Landschützer, P., Gruber, N., Chou, L., \& Regnier, P. (2019). The spatiotemporal dynamics of the sources and sinks of $\mathrm{CO}_{2}$ in the global coastal ocean. Global Biogeochemical Cycles, 33(12), 2019GB006239. https://doi.org/10.1029/2019gb006239

Tacconi' L., \& Muttaqin M. Z. (2020). Reducing emissions from land use change in Indonesia: An overview. Forest Policy and Economics, 108, 101979.

van der Werf, G. R., Randerson, J. T., Giglio, L., van Leeuwen, T. T., Chen, Y., Rogers, B. M., Mu, M., van Marle, M. J. E., Morton, D. C., Collatz, G. J., Yokelson, R. J., \& Kasibhatla, P. S. (2017). Global fire 
emissions estimates during 1997-2016. Earth System Science Data, 9, 697-720.

Wanninkhof, R., \& McGillis, W. R. (1999). A cubic relationship between air-sea $\mathrm{CO}_{2}$ exchange and wind speed, Geophysical Research Letter, 26(13), 1889-1892.

Wanninkhof, R. (1992). Relationship between wind speed and gas exchange over the ocean, Journal of Geophysical Research, 97, 7373-7382.
Weiss, R. F., \& Price, B.A. (1980). Nitrous oxide solubility in water and seawater. Marine Chemistry, 8(4), 347-359.

Wirasatriya, A., Sugianto, D. N., Maslukah, L., Ahkam, M. F., Wulandari, S. Y., \& Helmi, M. (2020). Carbon dioxide flux in the Java Sea estimated from satellite measurements. Remote Sensing Applications: Society and Environment,

20 ,

1-13. 